\title{
Teaching Operations research, the experience of the Catholic University in Bolivia
}

\section{Héctor Reynaldo Córdova Eguívar}

Catholic University of Bolivia, Bolivia.

\begin{abstract}
The Catholic University of Bolivia undertook an experience to develop profesional competencies in students of Operations research and to position the tools of this specialty to help improve the management of private companies.

The paper presents the implementation of a new methodology (Project Based Learning) for teaching the subject of Operations Research to a group of students from different fields at a national context during a period of 5 years.

Students must perform a project on small companies in order to gain the competences related to the course of Operational Research. The paper analyzes the change of methods (from traditional ones based on the passive role of students to a participative model where student applies their knowledge to their daily activity) teaching mathematics in Bolivia. The company representatives play an active role monitoring and assessing the implementation process.

The evaluation of the students shows that the competency has been developed to the expected level and Operations research has now a place in the management of small companies.

Keywords: Teaching experience; Operations research; Project approach; Authentic evaluation.
\end{abstract}




\section{Introduction}

This document presents the experience from the Catholic Univesity of Bolivia in the last 5 years around teaching Operations Research to a group of students from different fields. This experience was developed in a national context that is very limited in industrial and company management aspects. Therefore, the strategies of this process focused on the improvement of the management of small companies. The course's aim is to increase the students' interest to attain a profesional competency to the planned level, and to extricate the procedural approach from mathematics teaching, in order to deepen the analysis and proposal.

The approach is Project Based Learning. The evaluation is authentic and the project implemented by the students in small companies is the tool to gather information necessary to verify the development of the competency. The companies' representatives become partners for the monitoring of the projects and for the evaluation of the competencies development.

The results that have been achieved during this period are encouraging in regards to a new way of teaching mathematics. Students show great interest about Operations research many tesis and dissertations use it as a main tool - in contrast to what happened before; the competency has been developed mostly by the students, they are more analytical and the proposals they present are coherent, judicious and feasible; additionally, more companies are being made aware of Operations research.

The main conclusion from this experience is that it is posible to tackle mathematics teaching in a different way, targetting significant learning and the need of every student to take responsibility for its education.

\section{Context}

Micro and small enterprises create jobs for a big amount of people, and their contribution to Bolivia's GDP is important, as they represent over $90 \%$ of the economic units in the country (Sistema integrado de información productiva, 2016), for this reason, the state has decide to strengthen their productive and managerial capacities (Viceministerio de micro y pequeñas empresas, 2019). The state recognises that the people who created these companies need training, and it has stablished appropriate mechanisms for this (Law 943 of micro and small enterprises, 2017, Art. 22nd). Along this line, the course on Operations Research in the Catholic University of Boliva is intended to contribute to this strengthening.

On the other hand, mathematics teaching in Bolivia follows the traditional line of emphasizing the procedural aspect. Classes on Calculus, in this University, teach students 
to derive functions, to calculate the limits and to integrate them. The tests, the same for all students, focus on the manual resolution of problems; students cannot use laptops, calculators, mobile phones (cellphones), or any support textbook, showing the importance of memorization of different topics instead of analysis.

Since the class of Operations Research sits at the Mathematics Department, the approach has traditionally been the same.

Nevertheless, the Competencies approach is, gradually, consolidating within the higher education system in Bolivia (Comité Ejecutivo de la Universidad Boliviana (CEUB), 2016, pp 77-80), and this has opened new opportunities for teaching mathematics, although there is strong resistance from the professors, particularly the older ones.

The Catholic University of Bolivia has started a process, since the beginning of the $21^{\text {st }}$ century, a change in their academic model, by focusing on the development of competencies. It started a sustained training process for professors, and many departments and careers have started its implementation. The Department of Basic Science - to which Operations research belongs is undergoing a slow transition, particularly in the Mathematics area.

Operations research is a discipline that consists of the application of advanced analytical methods to support decision-making processes, identifying the best possible courses of action. Operations research works with mathematic models, statistical analysis and mathematic optimization, to reach optimal solutions, or the closest alternative, to complex decision problems. The expectation is that the decisions made using operations research are better in comparison to those taken by following intuition or the experience of the person making those decisions (Mahto D, 2012). Its teaching, following a traditional approach, is reduced to theory and decontextualized examples, causing little interest in students and the unawareness of its virtues by companies.

In the Catholic University of Bolivia, this is a mandatory course for many fields, bringing together a heterogenous group of 50 students. These students are usually between the fourth and eighth semester of their careers, creating an environment that appears to be very complex to manage. On some occasions, students of other fields also choose to take this course voluntarily, making the group even more diverse

The students are $20-22$ years old, most of them male. They participate in one or many social networks and are, constantly, looking at their phones. They are very good at finding information online, but not as good when it comes to selecting valid information. Additionally, according to their explanation, they keep the information they find, but rarely read it. 
Few of them show their familiarity with the topic or how it could help their knowledge. At the moment of the diagnostic assessment their procedural capacity is evident, but it is also clear that they have conceptual and analytic weaknesses. They almost never anticipate the result of applying a procedure, and they are not used to confronting their results with a prior assumption, the result of the analysis of the situation.

During the last twenty years before this experience, there have been few dissertations using Operations research as a central element in this University.

\section{Method}

Due to the topic and the context, this course has three objectives: to propose an interesting study subject to the students, one that is also motivating and that will allow the discovery of the real potential of Operations Research; to develop a professional competence in the students and to position Operations Research as a tool that companies can use for their benefit.

The idea was to bring together the interests of students with the needs of the companies, using Operations Research as an intermediary. In this way, students would be involved in the development of the course, its implementation and the evaluation, to make them feel responsible and to make them see the need to get involved in national issues to contribute with technical solutions.

Students must develop a proposal to improve the performance of a small business. In order to do this, they must apply the techniques of operations research, make mathematical models, experiment with them, analyze the results, analyze the sensitivity of the answers and elaborate a coherent, feasible and sensible proposal to improve the performance of the company.

To help with the execution of the mathematical models of these tasks, during the semester, students face several related problems, but disconnected from the companies, the approach for these tasks is Problem Based Learning (PBL). The problems must guide and motivate them to work on their projects. A successful experience is to present them with a national issue (for example, prioritization of public investment projects in municipalities with a reduced budget), another problem of personal importance (for example, personal diet or a problem linked to their career) and others of general interest (for example allocation of scarce resources, location of deposits).

The evaluation of the development of the competency is authentic. The execution of the project is the means to decide whether the student has developed the competency to the desired level. 
During the PBL phases, they look for information and receive orientation from the professor; during the programmed class session, students work on the tools they will use at the computer lab, the specialized software and other operational details.

Table 1. Methodology

\begin{tabular}{|c|c|c|c|}
\hline & Methodology & Time & Activities \\
\hline 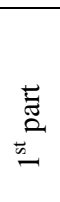 & $\begin{array}{l}\text { PBL National: } \\
\text { PBL General: }\end{array}$ & 2 weeks & $\begin{array}{l}\text { Search for information, model construction, model } \\
\text { resolution, result analysis, preparation of an } \\
\text { optimisation proposal, reflection and preparation of a } \\
\text { theory. }\end{array}$ \\
\hline 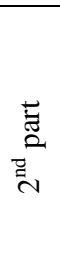 & Project based learning & 8 weeks & $\begin{array}{l}\text { Getting to know the company, interviews with key } \\
\text { people, document reading, identifying opportunities } \\
\text { for improvement, preparing mathematical models, } \\
\text { solving models, results analysis, analyzing the } \\
\text { sensitivity of the answers, preparing optimization } \\
\text { proposals, presenting these proposals }\end{array}$ \\
\hline
\end{tabular}

Source: Elaborated by the author

During the time of the intervention in the company, students have a self-regulation tool previously agreed on. This tool is used as a guide for weekly reports and is the selfassessment rubrique they apply to their research.

The authentic evaluation helps assess both the implementation process and the result (the proposal):

- There are three information sources for the final score over 100 points: students themselves (20), the entrepreneurs (30) and the professor (50).

- The rubric that is used has 8 criteria: relevance of the operation for research (relevance of the opportunities identified by the students) (10), the estimation of the results that could be achieved (the estimation is based on the student's analysis of the company's situation and its acceptance by the entrepreneur) (10), information gathering (respect to institutional principles, respect for the environment, gender) (10), the construction of the mathematic model (definition of variables, construction of restrictions) (15), its resolution and the sensitivity analysis (Thoroughness during result interpretation, creativity and comprehensiveness on the sensitivity analysis) (20), the preparation of the proposal (coherence and fesability) (25), the preparation of the document (completeness, ortograph) (5), and the presentation of the results (security, use of time) (5). 
- Entrepreneurs cooperate with the monitoring of the process criteria, the relevance of the opportunities identified by the students, the respect to institutional principles, respect for the environment and gender approach.

- The professor monitors the quality of the model, the comprehensiveness and relevance during the information gathering process, the thouroughness of the analysis of the results and the creativity and comprehensivess of the sensitivity analysis

- The entrepreneurs and the professor evaluate the result criteria.

- The students assess their progress on all regards

\section{Execution and results}

Table 2 shows the results of the experience, including the number of registered students, those who managed to develop the competence and the companies in which they worked. As of 2016, two more groups were increased per semester.

Table 2. Results of this experience

\begin{tabular}{ccccc}
\hline Year & $\begin{array}{c}\text { Number of } \\
\text { students }\end{array}$ & $\begin{array}{c}\text { Number of } \\
\text { students } \\
\text { approved }\end{array}$ & $\begin{array}{c}\text { Number of } \\
\text { groups }\end{array}$ & $\begin{array}{c}\text { Number of } \\
\text { companies }\end{array}$ \\
\hline 2014 & 96 & 93 & 29 & 27 \\
2015 & 93 & 82 & 27 & 27 \\
2016 & 171 & 138 & 44 & 42 \\
2017 & 197 & 189 & 61 & 60 \\
2018 & 197 & 191 & 62 & 62 \\
\hline
\end{tabular}

Source: Elaborated by the author

As part of the preparation phase, each semester, it was important to find small companies that were willing to receive the students groups and give them the information that would allow them to undertake their research. Afterward students chose the problems they would tackle during the semester. The solutions to these problems would support and complement the execution of the research and the transfer of what they learned.

The presentation of the methodology for the course caused different reactions in the students: interest for a different approach, motivation about participating in decision making spaces in regards to the problems to face. 
The development of the theory from the experience was another novelty for students and was the most difficult part to assimilate for them. Having to do the analysis and estimations before applying a formula made them feel insecure, and it was important to motivate them continually. WhatsApp was a good tool for this, and in some cases, individual communication could be useful.

Halfway through, there is a written evaluation about the process, what they learned, the difficulties and how to improve the work. The enthusiasm is general. The causes, according to the students are: the importance of being responsable for their learning, working on national issues, the challenges they fase and feeling useful to provide solutions to real issues from outside entities.

Conversely, there is always one or two students who feel uncomfortable with the method used, and who express their desire to go back to the traditional method: "Why does the professor not do his job? We pay him to teach, not for him to make us do what he should be doing" said a student once. In every case, these students said that theory should always be tought before practice; they said that they felt bad about facing situations without the necessary tools. This position was contested enthusiastically by their fellows. The final evaluation of the course presents suggestions made by the students on operational aspects, such as having more time, having the opportunity to change groups in the middle of the semester, having more classes per week and working on more examples.

The experience in the companies has been positive, both for the companies and the students. The competency was developed to the expected level. The most important indicator was the acceptance of the proposal by the companies, and this happened in almost every case. From over one hundred companies, only three rejected the proposals made by the students.

At the beginning of the students' intervention, the companies show lack of trust and difficulties to share information; but this attitude changes as the weeks pass and they perceive the role of the students as mutual collaboration.

In all cases the companies' representatives expressed their gratefulness to the University for giving them the attention and support in their management. They also showed their satisfaction for the students' behaviour and because their research allowed them to see solutions to their problems that they had not perceived.

The evaluation uses information from the companies' representatives, the students and the professor,

The reports prepared by the companies about the work of the students is honest and, in some cases, quite severe. They show the detail about attendance, punctuality, treatment of workers, the accuracy of their observations, the pertinence of their decisions and the 
viability of their final proposal. In five cases the companies have tried to recruit the students to strengthen their teams, happy with the work they did and because the proposals had helped improve their performance. The students' self-assessment shows that they feel they developed the competency according to the expectations.

In the last 4 years, there have been ten dissertations that use Operations research as a main issue, although over 500 students have been working with this new methodology.

\section{Conclusions}

The most important conclusion is that using different methods to the usual has allowed the development of a profesional competency on Operations research, to the desired level, in students from different fields. The second is that, by interacting with small companies, it is possible to show that ther are powerful tools that, if used appropriately, can help improve their performance.

On the other hand, involving students in Operations Research for their learning has proven to be an important motivating factor, as well as the incorporation of mechanisms of selfregulation helps them control the quality of their work.

As for the role of the companies' representatives, it has been very effective, and has contributed to the training and evaluation of the students. This different way of teaching mathematics can serve as an example for other courses in which mathematics is essential.

\section{References}

Comité Ejecutivo de la Universidad Boliviana. (2016). Modelo académico del sistena de la universidad boliviana 2015 - 2019 . La Paz: Comité Ejecutivo de la universidad boliviana.

Gaceta Oficial del Estado Plurinacional de Bolivia. (2017). Ley 943 de la micro y pequeña empresa. La Paz: Gaceta Oficial.

Mahto Dalgobind. (2012). Essentials of Operations Research. Retrieved January 27, 2019 form https://www.academia.edu/23076206/ESSENTIALS_OF_OPERATIONS_RESEARCH

Sistema integrado de información productiva. (2016). SIIP. Retrieved January 27, 2019 from http://siip.produccion.gob.bo/repSIIP2/mapaUE.php

Viceministerio de la micro y pequeña empresa. (2019). Ministerio de desarrollo productivo y economía plural. Retrieved January 31, 2019 from http://produccion.gob.bo/viceministerios/viceministerio-de-la-micro-y-pequenaempresa/ 